\title{
Effect of cows lineage on milk and butter composition in black- motley cows
}

\author{
$V$ Babushkin, $A$ Negreeva, $A$ Gagloev \\ Michurinsk State Agrarian University, Michurinsk, Russia
}

\begin{abstract}
The paper presents the results of the study into the composition and properties of milk in blackand-white dairy cows improved using black-and-white Holsteins of different lines. It has been found that cows of the Vis Ideal line produce milk with a high casein and phosphorus content, cows of the Poseidon line give milk with a high content of whey proteins, and cows of the Annas Adema line produce milk with a high lactose and calcium content. Milk from cows of the Vis Ideal line is most suitable for the production of high-quality dairy products such as butter and cheese. Usinng the milk of cows of the VIs Ideal line is better for the production of high-quality dairy products. The milk of all the analyzed genotypes is suitable for the production of high-quality sweet cream butter, but the most qualitative product is obtained when using the milk of cows of black-and-white improved cattle of the Vis Ideal line.
\end{abstract}

\section{Introduction}

Milk is a product that can be used both in raw and processed form. It contains highly digestible nutrients and related substances that are necessary for a newborn to build a body: proteins, fats, carbohydrates, minerals, vitamins, water. All components of milk are in the aqueous phase in coarse, colloidal or soluble form. The ratio of substances contained in milk is different for different species and breeds of animals. Due to the fact that black-and-white cattle were improved using blackand-white Holsteins on most farms, it is of great interest to study the composition and properties of milk from cows of different genotypes. Therefore, the study aimed to investigate the physicochemical composition and technological properties of milk from black-and-white cows of different origin in conditions of intensive technology on one of the leading farms in the region [14].

\section{Materials and methods}

The study was carried out at JSC Golitsyno, Nikiforovsky district, Tambov region. The conditions of feeding and housing in the study period were quite stable and did not cause significant fluctuations in the level of manifestation of the considered indicators. For the experiment, 6 experimental groups of cows were formed according to the principle of balanced groups. Each group included 10 first-calf heifers of different lines: the Vis Ideal 933122 for the first group, the Annas Adema line 30587 for the second group, the Rikus line 25415 for the third group, the Poseidon line 239 for the fourth group, the Reflection Sovereing lines 198998 for the fifth group, and the Frans 11881 line for the sixth group. The composition and properties of milk were studied by to the following indicators: fat (Klever $1 \mathrm{M}$ analyzer); lactose (refractometric method); protein (Klever 1M analyzer); the size and number of fat globules (counting in the Goryaev chamber); caloric content (calculation method); titratable acidity, in Turner's degrees $\left({ }^{\circ} \mathrm{T}\right)$ in accordance with GOST 3624-87; cheese suitability (rennet-fermentation sample); heat stability (alcohol test).

Milk selected from 5 cows in each group at 4-5 months of lactation of the lines Vis Ideal 933122, Annas Adema 30587, Rikus 25415, Poseidon 239 was used to produce sweet cream butter. The production of sweet cream butter was carried out at JSC "Novopokrovsky" cheese and butter factory according to GOST 32261-2013Butter. The next day after churning, when analyzing the finished product, a commission-closed examination and a physico-chemical analysis for the content of fat, moisture, acidity, etc. were carried out. To characterize the fat phase of the butter, the iodine value, peroxide number and saponification number, thermal stability were studied using generally accepted methods[10].

\section{Results and discussion}

Milk proteins consist of casein and whey proteins. Proteins contain about $80 \%$ casein and $20 \%$ whey proteins. Milk proteins are the basis for cheese preparation and production of concentrated dairy products and milk powder, therefore, assessment of the protein content in milk is relevant [5].

The composition and amount of proteins in milk of cows of different genotypes are shown in Table 1.

Table 1 shows that the lowest casein content of $2.50 \%$ and $2.55 \%$ was observed in milk of the Poseidon 
and Reflection Sovereing lines, which is less by $0.2 \%$ and $0.15 \%(\mathrm{P}<0.95)$ compared to the Vis Ideal line, by $0.15 \%$ and $0.1 \%$ compared to the Rikus line, and by $0.12 \%$ and $0.07 \%$ compared to the Frans line. The highest casein content of $2.70 \%-2.65 \%$ was found in milk of Vis Ideal and Rikus lines.

Cows of the Poseidon and Annas Adema lines were superior in terms of the serum protein content $(0.74 \%$ albumin and $0.7 \%$ globulin), which was significantly higher than that in the Frans and Reflection Sovereing lines.
Therefore, the Vis Ideal and France lines are most suitable to increase the amount of milk proteins, such as casein and whey proteins.

A high content of milk sugar was found in milk of the Annas Adema and Vis Ideal lines (4.88 and 4.86\%, respectively), which exceeded the milk sugar content of the Rikus and Reflection Sovereing lines by 0.35 and $0.29 \% \quad(\mathrm{P} \geq 0.99)$, and 0.33 and $0.27 \% \quad(\mathrm{P} \geq 0.95)$, respectively.

Table 1. Chemical composition of milk from cows of different lines.

\begin{tabular}{|l|l|l|l|l|l|l|}
\hline \multirow{2}{*}{ Line } & $\begin{array}{l}\text { Casein } \\
\text { content, } \%\end{array}$ & $\begin{array}{l}\text { Whey protein } \\
\text { content, } \%\end{array}$ & $\begin{array}{l}\text { Lactose } \\
\text { content, } \%\end{array}$ & Ash, \% & $\begin{array}{l}\text { Calcium, } \\
\mathrm{mg} / \%\end{array}$ & $\begin{array}{l}\text { Phosphorus, } \\
\mathrm{mg} / \%\end{array}$ \\
\cline { 2 - 7 } & $\mathrm{M} \pm \mathrm{m}$ & $\mathrm{M} \pm \mathrm{m}$ & $\mathrm{M} \pm \mathrm{m}$ & $\mathrm{M} \pm \mathrm{m}$ & $\mathrm{M} \pm \mathrm{m}$ & $\mathrm{M} \pm \mathrm{m}$ \\
\hline Vis Ideal & $2.70 \pm 0.03$ & $0.68 \pm 0.01$ & $4.86 \pm 0.01$ & $\begin{array}{l}0.71 \\
0.004\end{array}$ & $125.8 \pm 0.3$ & $98.3 \pm 0.4$ \\
\hline Annas Adema & $2.56 \pm 0.03$ & $0.70 \pm 0.01$ & $4.88 \pm 0.02$ & $\begin{array}{l}0.72 \\
0.004\end{array}$ & $126.7 \pm 1.1$ & $98.0 \pm 0.8$ \\
\hline Rikus & $2.65 \pm 0.01$ & $0.69 \pm 0.01$ & $4.53 \pm 0.01$ & $\begin{array}{l}0.70 \\
0.004\end{array}$ & $125.1 \pm 0.5$ & $97.2 \pm 0.3$ \\
\hline Poseidon & $2.50 \pm 0.02$ & $0.74 \pm 0.01$ & $4.80 \pm 0.02$ & $\begin{array}{l}0.71 \\
0.003\end{array}$ & $125.0 \pm 0.9$ & $95.0 \pm 0.5$ \\
\hline $\begin{array}{l}\text { Reflection } \\
\text { Sovereing }\end{array}$ & $2.55 \pm 0.02$ & $0.66 \pm 0.01$ & $4.59 \pm 0.01$ & $\begin{array}{l}0.70 \\
0.003\end{array}$ & $124.4 \pm 1.1$ & $93.9 \pm 1.1$ \\
\hline Frans & $2.62 \pm 0.02$ & $0.66 \pm 0.01$ & $4.82 \pm 0.02$ & $\begin{array}{l}0.71 \\
0.004\end{array}$ & $125.4 \pm 0.9$ & $95.9 \pm 0.3$ \\
\hline
\end{tabular}

Animals get mineral substances that pass into milk mainly from feed and mineral supplements. Therefore, the amount of these substances in milk directly depends on the ration, season, environment, as well as on the breed and physiological characteristics of the animal. Data on the content of mineral substances in milk are presented in Table 1. The table show that the percentage of ash in milk from cows of different lines is almost similar -0.71 and $0.70 \%$, except for the Annas Adema line with the ash content higher than $0.1-0.2 \%$.

The calcium content in milk exhibited the following tendency. The lowest calcium content $(124.4 \mathrm{mg} / \%)$ was found in milk of the Reflection Sovereing line, and the highest one (126.7 mg /\%) - in the Annas Adema line. It should be noted that in spite of this, the study did not reveal significant differences between the calcium content in milk of cows of different lines $(\mathrm{P} \leq 0.95)$.

However, in terms of the phosphorus content, a significant difference could be observed between the Vis
Ideal and Poseidon, Frans and Reflection Sovereing lines by $3.3,2.4$ and $4.4 \mathrm{mg} / \%(\mathrm{P} \geq 0.99)$, respectively, in favor of the Vis Ideal line.

One of the main indicators of the technological properties of milk as a raw material for buttermaking is the number of fat globules per $1 \mathrm{ml}$ of milk and the average diameter of globules. The size of milk fat globules has a significant impact on the process of butter formation and on the degree of use of fat during churning. When an average diameter of milk fat globules is $2-3 \mu \mathrm{m}$, the degree of use of milk fat is $68 \%$, for $3-4$ $\mu \mathrm{m}$ globules $-78 \%$, and for $8 \mu \mathrm{m}$ globules $-100 \%$. The size of milk fat globules depends on feeding, lactation stage, and breed [4, 6, 7]. On average 3-5 billion fat globules with a diameter of $2.5-3.5 \mu \mathrm{m}$ can be observed in $1 \mathrm{ml}$ of milk. Table 2 shows that milk of cows of the studied lines differed in the number and size of fat globules.

Table 2. Technological properties of milk from cows of different lines.

\begin{tabular}{|l|l|l|l|}
\hline Line & Number of fat globules, bln/ml & Average diameter of globules, $\mu \mathrm{m}$ & Duration of coagulation, min \\
\hline Vis Ideal & $3.30 \pm 0.18$ & $3.18 \pm 0.21$ & $26.4 \pm 0.3$ \\
\hline Annas Adema & $3.24 \pm 0.14$ & $2.80 \pm 0.16$ & $28.9 \pm 0.3$ \\
\hline Rikus & $3.29 \pm 0.16$ & $3.16 \pm 0.19$ & $27.1 \pm 0.1$ \\
\hline Poseidon & $3.20 \pm 0.12$ & $2.76 \pm 0.10$ & $30.1 \pm 0.2$ \\
\hline $\begin{array}{l}\text { Reflection } \\
\text { Sovereing }\end{array}$ & $3.18 \pm 0.14$ & $2.74 \pm 0.09$ & $30.9 \pm 0.2$ \\
\hline Frans & $3.22 \pm 0.12$ & $2.74 \pm 0.10$ & $27.8 \pm 0.1$ \\
\hline
\end{tabular}


As can be seen from Table 2, the largest number of fat globules was observed in milk of the Vis Ideal and Rikus lines and amounted to 3.30 and $3.29 \mathrm{bln} / \mathrm{ml}$, respectively. The lowest number of globules was noted for the Reflection Sovereing and Poseidon lines - 3.18 and $3.20 \mathrm{bln} / \mathrm{ml}$, respectively. However, the obtained differences are not reliable. There were no significant differences in the number of fat globules in milk of different lines of cows.

The largest diameter of milk fat globules was observed in milk of the Wes Ideal and Rikus lines and amounted to 3.18-3.16 $\mu \mathrm{m}$, which is greater by 0.44 and $0.42 \mu \mathrm{m}(\mathrm{P} \geq 0.95)$ compared to the globules in milk of the Frans and Reflection Sovereing lines, and by 0.42 and $0.40 \mu \mathrm{m}(\mathrm{P} \geq 0.95)$ compared to the globules in milk of the Poseidon line. All this indicates that it is possible to obtain high quality butter from milk of cows of the studied lines.

Rennet clotting is one of the most important indicators to assess the quality of milk for cheese production, which depends on many factors, including breed and feeding conditions. As reported in [5, 7-10], a decrease in the content of main protein components is accompanied by an increase in the coagulation duration and a deterioration in the rennet properties (density and elasticity). In this regard, rennet coagulation of milk from cows of the studied genotypes was investigated (Table 2 ).

The results of the study revealed the best rennet coagulation in milk of cows of the Vis Ideal line (26.4 $\min$ ), and the worst rennet coagulation in cows of the Reflection Sovereing and Poseidon lines (30.9 and 30.1 $\mathrm{min}$ ). A reliable difference between these lines was 4.5 and $3.7 \mathrm{~min}(\mathrm{P} \geq 0.999)$. The rennet coagulation observed in milk of the Vis Ideal and Annas Adema lines was 2.5 and 1.4 min $(\mathrm{P} \geq 0.999)$ compared to the Frans line, and 0.7 min $(\mathrm{P} \leq 0.95)$ compared to the Rikus line.

Thus, cows of the Vis Ideal line should be used for the production of milk with a high casein and phosphorus content, the Poseidon line - for milk with a high whey protein content, and the Annas Adema line for milk with a high lactose and calcium content. At the same time, milk of cows of the Vis Ideal line are suitable for the production of high-quality dairy products such as butter and cheese.

Data on the physico-chemical parameters of sweetcream butter obtained from the milk of cows of different genotypes of butter are presented in Table 3 .

Table 3. Physico-chemical parameters of butter produced from milk of cows of different genotypes

\begin{tabular}{|l|l|l|l|l|l|l|l|}
\hline $\begin{array}{l}\text { Cows } \\
\text { genotype }\end{array}$ & $\begin{array}{l}\text { Thermal } \\
\text { stability }\end{array}$ & $\begin{array}{l}\text { Humidity, } \\
\%\end{array}$ & $\begin{array}{l}\text { Fat } \\
\text { content, } \%\end{array}$ & $\begin{array}{l}\text { Acid } \\
\text { content, } \mathrm{K}^{\mathrm{o}}\end{array}$ & $\begin{array}{l}\text { Peroxide } \\
\text { number }\end{array}$ & $\begin{array}{l}\text { Saponification } \\
\text { number }\end{array}$ & $\begin{array}{l}\text { Iodine } \\
\text { value }\end{array}$ \\
\hline $\begin{array}{l}\text { Vis Ideal } \\
933122\end{array}$ & 0,95 & 14,4 & 83,6 & 0,96 & 0,092 & 232,7 & 34,0 \\
\hline $\begin{array}{l}\text { Annas } \\
\text { Adema 30587 }\end{array}$ & 0,88 & 15,2 & 82,6 & 0,67 & 0,112 & 231,3 & 35,5 \\
\hline Rikus 25415 & 0,90 & 14,8 & 83,2 & 0,70 & 0,093 & 231,3 & 35,0 \\
\hline Poseidon 239 & 0,86 & 15,6 & 82,3 & 0,62 & 0,115 & 231,3 & 35,6 \\
\hline
\end{tabular}

slightly from each other (within $0.6 \%$ ) and meets the

The data in Table 3 indicate that the amount of moisture in the milk butter of the studied genotypes ranged from $14.4 \%$ to $15.6 \%$. The highest amount of moisture was found in the butter obtained from the milk of cows Vis Ideal line- $14.4 \%$, as well as from the Rikus line-14.8\%. The butter obtained from the milk of Poseidon line has the highest percentage of humidity $15.6 \%$. This indicator outweighs the percentage of moisture content of butter from the milk of Vis Ideal line by $1.2 \%$, Rikus - by $0.8 \%$. and Annas Adema - by $0.4 \%$.

According to the GOST requirements, the average percentage of moisture content in traditional sweet and creamy unsalted butter should be no more than $16 \%$, which corresponds to the indicators of the butter obtained from all the studied genotypes.

The lowest percentage of fat content was observed in the butter obtained from the milk of cows of the Poseidon line $-82.3 \%$, which is $0.2 \%$ lower than the requirements of GOST for this type of product. The highest percentage of fat content was observed in the butter obtained from the milk of cows of the Vis Ideal line, which is $1.3 \%$ more than that of the Poseidon line. The percentage of fat in the butter obtained from the milk of the other genotypes presented in the table differs regulatory requirements for the quality of this type of product.

The acidity of the butter is due to the presence of free fatty acids and the residual content of proteins. The butter produced from the milk of cows of the Vis Ideal line had the highest acidity, which is 0.34 higher than the lowest acidity index of the butter obtained from the milk of cows of the Poseidon line. However, as noted by Skorkina I. A. and others, the indicator of the acidity of the fat phase is considered to be the main criterion for oxidative spbutterage of butter is biased. According to the results obtained, it was also found that this indicator changes slightly during the storage of butter, while the indicators of the peroxide number and fat oxidation, which are directly related to the processes of oxidative spbutterage, had more significant changes, especially during long-term storage of butter at plus temperatures [4.10].

The ratio of high-melting, medium-melting and liquid fractions in butter is directly related to the chemical composition of fat, and in particular, with the iodine value. It is believed that the lower it is, the higher the content of high - melting glycerides in fat and lowerlow-melting ones. The iodine value characterizes the 
total number of unsaturated fatty acids and is an important indicator when evaluating the butter.

According to many authors, the iodine value of butter ranges from 35.2 to 40.8 with an average value of 37.6. At a low value of the iodine value, the butter has an excessively solid consistency, and at a high (38 or more) it becomes soft. This is due to the fact that the main unsaturated fatty acid, oleic, is in a liquid state at room temperature and softens the consistency of butter. The butter, in which milk fat is characterized by a large iodine value, is less resistant during storage [4].

Studies have shown that the lowest indicator was observed in butter obtained from the milk of cows of the Vis Ideal line (34.0). The highest value was noted in the butter from the milk of cows of the Poseidon line-35.6, which is 1.6 more than in the Vis Ideal line by 1.6. The difference between the values of the iodine value in the butter from other lines is about 0.5 .

The quality is characterized not only by the iodine value, there are other constants that characterize the properties of milk fat, for example, the peroxide number (if more than 1, the butter is not suitable for storage).

The peroxide value, which is characterized by the presence of peroxides in the butter formed as a result of fat oxidation, was not high in all samples (0.092-0.115), since fresh butter was studied.

Another indicator of the quality of butter is the thermal stability, which characterizes the ability of the butter to retain its shape under the action of its own mass at a temperature of $30^{\circ} \mathrm{C}$ for 2 hours, and is specified in the requirements of GOST. It is one of the indicators of the correct choice of the heat treatment mode. One of the main reasons for the non-thermal stability of the butter is the increased amount of low-melting triglycerides and polyunsaturated fatty acids in milk fat [10]. As studies have shown, the heat resistance of butter samples of all studied genotypes according to the GOST scale had a good heat resistance, which ranged from 0.86 to 0.95 .

To assess the quality of the butter, along with physical and chemical assessment methods, its organoleptic indicators are also used. A good butter should have a certain taste, aroma, consistency and, if possible, preserve these properties for a long time during storage. Sweet-cream butter according to GOST should have a pronounced creamy taste and taste of pasteurization, without foreign tastes and odors, the consistency is dense, plastic, homogeneous, the surface on the cut is shiny, dry in appearance. The color of the butter is from light yellow to yellow, uniform throughout the mass.

Organoleptic express assessment (Table.4) samples of butter from the milk of cows of all studied genotypes were carried out by 5 tasters. In accordance with GOST, a 20-point scale was used. According to this scale, the maximum score is given for taste and smell-10, consistency and appearance-5, color-2, packaging and labeling-3 points.

Table 4. Organoleptic evaluation of experimental samples of sweet butter

\begin{tabular}{|l|l|l|l|l|l|l|}
\hline \multirow{2}{*}{ Genotype } & \multicolumn{2}{|l|}{ Indicators in points } & \multirow{2}{*}{ Total } & \multirow{2}{*}{ Variety } \\
\cline { 2 - 6 } & $\begin{array}{l}\text { taste and } \\
\text { smell }\end{array}$ & consistency & Color & $\begin{array}{l}\text { Packaging } \\
\text { and labeling }\end{array}$ & & premium \\
\hline Vis Ideal 933122 & $4,8 \pm 0,11$ & $5,0 \pm 0,20$ & $5,0 \pm 0,10$ & $5,0 \pm 0,11$ & $19,8 \pm 0,15$ & premium \\
\hline $\begin{array}{l}\text { Annas Adema } \\
30587\end{array}$ & $4,4 \pm 0,13$ & $4,7 \pm 0,16$ & $5,0 \pm 0,11$ & $5,0 \pm 0,10$ & $19,1 \pm 0,12$ & premium \\
\hline Rikus 25415 & $4,6 \pm 0,15$ & $4,8 \pm 0,13$ & $5,0 \pm 0,11$ & $5,0 \pm 0,12$ & $19,4 \pm 0,14$ & premium \\
\hline Poseidon 239 & $4,3 \pm 0,12$ & $4,4 \pm 0,11$ & $5,0 \pm 0,10$ & $5,0 \pm 0,11$ & $18,7 \pm 0,11$ & \\
\hline
\end{tabular}

During the organoleptic evaluation of taste and smell, there were no significant differences between the butter obtained from cows of different genotypes. All types of butter received such an assessment that the taste was pure, but not sufficiently pronounced. As for the average score for taste and smell, the highest score was given to the butter produced from the milk of cows of the Vis Ideal line, as well as from cows of the Rikus line. The lowest score was obtained by butter from the milk of Poseidon cows-4.3.

According to the consistency, all types of butter had a slightly crumbly consistency, which is explained by the content of the iodine number within its extreme value of 35.2. The butter obtained only from the milk of cows of the Vis Ideal line had a non-crumbly consistency. This butter, in turn, received the highest average score when evaluating the consistency - 5.0. The lowest average score for consistency equal to 4.4 was obtained by butter produced from the milk of Poseidon cows.

All types of butter had a natural color characteristic of this product and received an average score of 5.0.
At the end of the assessment, the points were summed up. The highest amount of points was received by the butter produced from the milk of cows of the Vis Ideal line - 19.8 points. The butter obtained from the milk of cows of the Rikus line received 0.4 points less. The lowest score was given to the butter obtained from the milk of Poseidon cows -18.7.

As a result, all four prototypes of sweet-cream butter were evaluated by the highest grade according to organoleptic indicators.

Thus, the milk of all the analyzed genotypes is suitable for the production of high-quality sweet butter, but the highest quality product is obtained when using the milk of cows of black-and-white improved cattle of the Vis Ideal line.

\section{References}

1. I.A. Skorkina, S.A. Lamonov 2018 Production of environmentally safe beef in Tambov oblast 
International Journal of Mechanical Engineering and Technology 9 1206-1214.

2. D.S. Vilver 2018 Effect of selection on the milk productivity of black-and-white cows of different lines Topical issues of biotechnology and veterinary medicine: theory and practice. Proceedings of the National Scientific Conference of the Institute of Veterinary Medicine 31-35.

3. S.A. Lamonov, A.S. Safonova 2019 Age-related changes in the morphological and functional properties of the udder of Simmental cows and their crosses with the red-and-white Holstein breed Bulletin of Michurinsky State Agrarian University 3(58) 101-104.

4. I.A. Skorkina, N.V. Grikhina 2019 Quality of butter made from milk of red-and-white cows depending on the line Bulletin of Michurinsky State Agrarian University 2 127-129.

5. O.V. Svitenko, V.V. Zatuleev, A.S. Bardak 2016 Chemical composition of milk of Holstein cows of different lines Academic Science - Problems and Achievements VIII. Proceedings of the VIII international scientific and practical conference 92-94.

6. S. Tumino et al. 2021 Feeding system resizes the effects of dgat1 polymorphism on milk traits and fatty acids composition in modicana cows Animals 11(6)1616

7. S. Karamaev, A. Karamaeva, N. Soboleva, L. Bakaeva 2019 Milk productivity of cows when haylage with biological preservatives is included in the diet IOP Conference Series: Earth and Environmental Science 403(1) 012081.

8. A.V. Randelin, T.N. Barmina, S.A. Surkova, A.A. Kaidulina, A.S. Mokhov 2016 Effect of line on the milk productivity of Holstein cows Development of innovative technologies for the production of livestock raw materials and food products based on modern biotechnological methods. Proceedings of the International Scientific and Practical Conference. LLC Sphere, Povolzhsky Research Institute for the production and processing of meat and dairy products, Volgograd State Technical University 47-51.

9. I.O. Snezhko 2018 Effect of the duration of economic use of cows of the Belarusian blackand-white breed of various lines on their productivity Agronomy. Plant protection. Storage and processing technology for agricultural products. Veterinary medicine. Animal science. Proceedings of the XIX International Student Scientific Conference. Grodno State Agrarian University 365-367.

10. Skorkina I.A., Lamonov S.A. 2019 Comprehensive assessment of meat from steers of various genotypes as the raw material for obtaining food products for children Research Journal of Pharmacy and Technology 12(12) 5664-5668.

11. Tepel A. Chemistry and physics of milk. (St. Petersburg: Profession, 2012) 